\title{
Germination characteristics of different maize inbred hybrids and their parental lines
}

\author{
S. Omar ${ }^{1} \cdot$ Á. Tarnawa $^{1} \cdot$ Z. Kende $^{1}$ (D) R. Abd Ghani ${ }^{1} \cdot$ M. K. Kassai ${ }^{1} \cdot$ M. Jolánkai ${ }^{1}$
}

Received: 26 July 2021 / Accepted: 22 January 2022 / Published online: 7 February 2022

(c) The Author(s) 2022

\begin{abstract}
The germination characteristics response for some selected maize hybrids and their parental inbred lines were observed and evaluated in an in vitro trial. The aim of the study was to determine the differences within the performance of some hybridization pathways. Single cross (SC), double cross (DC) and three-way cross (TC) hybrids and their parental inbred lines were studied. The results showed that the germination of maize seeds started after the third day and completely germinated on the seventh day after sowing. Hybrids SC $\left(\mathrm{F}_{1}\right)$, DC $\left(\mathrm{F}_{1}\right)$, and TC $\left(\mathrm{F}_{1}\right)$ showed excellent germination performance with a $100 \%$ germination rate on the fifth day and produced the highest shoot and root lengths with $7.9 \mathrm{~cm}, 7.6 \mathrm{~cm}$, and $6.9 \mathrm{~cm}$ (shoot length) and $12.9 \mathrm{~cm}, 13.9 \mathrm{~cm}$ and $14.9 \mathrm{~cm}$ (root length), respectively. Thus, the results obtained clearly show that the hybrid seeds have higher germination rate $(100 \%)$, and the seedlings were more vigorous compared to the parents.
\end{abstract}

Keywords Germination characteristics $\cdot$ Maize $\cdot$ Inbred hybrids

\section{Introduction}

Maize or corn (Zea mays L.) is one of the most important grain crops cultivated in many parts of the world. It is a vital source of carbohydrates and other nutrients as well as phytochemical compounds. Global maize production has raised surpassing other cereal crops making it the most valuable staple food besides wheat and rice (Fortuna et al. 2020; Rouf Shah et al. 2016). In addition to selecting the superior varieties plus increasing the maize production value, farmers also focus on the quality aspect of seeds. This is a fundamental assessment method that can differentiate the seed's physiological potential at different stages of seed production level. The outcomes will support the selection of high-quality seeds to meet consumer requirements. This information will assure that the promising variety will produce the best result after planting based on seed viability and seed vigour. Thus, seed information and assessment also provide benefits and advantages in the seed industry (Marcos 2015).

\section{Z. Kende}

kende.zoltan@uni-mate.hu

1 Department of Agronomy, Hungarian University of Agriculture and Life Sciences, Páter Károly utca 1, 2100 Gödöllő, Hungary
Maize production is mainly based on the use of inbred hybrids all over the world. Maize breeding and the seed propagation of a certain hybrid are done in accordance with the type of the hybrid. In Hungary, the first maize hybrid was Mv 5 that registered in 1953. From 1964 onwards, 100\% of the maize-growing area in Hungary was occupied by hybrid maize (Marton 2013). Besides, single cross (SC), double cross (DC) and three-way cross (TC) hybrids as well as some modified versions of these three combinations are used in commercial cultivation. The reason to cultivate hybrids rather than open-pollinated varieties is the heterosis effect of $F_{1}$ generations (Nagy 2008; Berzy et al. 2020). Heterosis may be defined as the superiority of an $F_{1}$ hybrid over both its parents in terms of yield or some other character. Heterosis, or hybrid vigour, describes the superior performance of heterozygous hybrid individuals compared with their homozygous parental inbred lines (Britannica 1998).

In 1876, Fedrich Nobbe was the first to distinguish the concept of seed vigour from germination (Copeland and McDonald 1999). Over the last decade, seed vigour testing has become more important for quality control and marketing in seed industries. Both seed producers and farmers need repeatable testing and accurately describe the emergence potential of the seed companies (Byrum and Copeland 1995). Franck (1950) insisted that germination tests must be conducted under favourable conditions. 
The ability to produce plants in seed lot farms should be defined by a new term: vigour.

In addition, the germination testing purpose is to determine the percentage of seeds alive in any seed lot. It also shows that germination is associated with seed vigour and provides an excellent estimate of field performance. Although the germination rate slightly varies between varieties, the seeds should absorb moisture within two days and produce the first roots and leaves in four days. At this point, the seeds are considered as germinated seedlings. According to Goggi et al. (2008), seed quality is described as a seed viability and vigour, which allows normal seedlings to emerge in a various of field conditions. The SC test, the accelerated ageing (AA) test, and the Soak test are some of the procedures used to assess seed quality.

The uniform and vigorous seedling emergence will ensure a good plant population and yield (Shirin et al. 2008). This information is vitally important because it is related to field emergence performance, seedling establishment, and the subsequent performance of the plant produced (Abbasian et al. 2013). In addition, germination is an indicator of viability, which specify as the property of the seeds that can allow them to germinate in optimal conditions (Baldwin et al. 2006). Berzy et al. (2020) have underlined the importance of maternal cross-combination effects, and there is a correlation between seed vigour, fresh shoot weight, fresh root weight, and kernel yield in most maize hybrids.

Therefore, the current study investigates the germination characteristics response for some selected maize hybrids and their parental inbred lines. The aim of the study was to determine the differences within the performance of some hybridization pathways. Results of this study may be beneficial for future breeding, propagation and production purposes.

\section{Materials and methods}

\section{Planting materials}

The maize seed varieties in this study were obtained from the Agricultural Research Center, Martonvásár, Hungary. Single cross (SC), double cross (DC) and three-way cross (TC) hybrids and their parental inbred lines were studied. Four parents, viz. B1026/17 (SC (F)), TKAPA/15/ DV (SC (M)), TK1083/19 (DC (F)) and, MCS901/19 (TC (F)) together with three hybrids; B1026/17 $\times$ TKAPA/15/ DV $\left(\operatorname{SC}\left(\mathrm{F}_{1}\right)\right)$, TK1083/19 $\times \mathrm{MCS} 901 / 19\left(\mathrm{DC}\left(\mathrm{F}_{1}\right)\right)$, and MCS $901 / 19 \times \mathrm{B} 1026 / 17\left(\mathrm{TC}\left(\mathrm{F}_{1}\right)\right)$ were tested in this trial. All maize seeds used have been treated with fungicide to prevent any fungus infections.

\section{Growing conditions}

The trials were conducted in January 2021 at the Laboratory of Crop Production of the Institute of Agronomy, Hungarian University of Agricultural and Life Sciences (MATE), Gödölló, Hungary. The standard germination test was applied where all seeds were allowed to germinate in $13.5 \mathrm{~cm}$ Petri dishes, lined with single layer Whatman filter paper (AOSA 1992). The filter paper was moistened with $8 \mathrm{ml}$ distilled water at the beginning and added $10 \mathrm{ml}$ on day seven of the trial. Each treatment contained five seeds and was laid out in a completely randomized block design with four replicates. Then, the seeds were incubated in a growth chamber at $23{ }^{\circ} \mathrm{C}$ for 12 days. The observation and data collection were recorded for germination rate (\%), root length $(\mathrm{cm})$, and shoot length $(\mathrm{cm})$ at $5,7,9,12$ days.

\section{Statistical analysis}

Analysis of variance (ANOVA) was performed using Statistic SPSSV.23 software. Data were subjected to a one-way analysis of variance to explain differences between maize varieties and treatment (days). The mean value of the treatment was compared with the least significant difference (LSD) at $p<0.05$. Post hoc test for multiple comparisons using the least significant difference (LSD) was also used at $p<0.05$.

\section{Results}

\section{Germination rate (\%)}

The ANOVA table (Table 1) revealed that there were no significant differences in germination rate between the groups of maize varieties $F(6,133)=1.759, p=0.112$. Germination started on the third day and was completed by the seventh day after placing seeds in the Petri dishes. All maize varieties had attained $100 \%$ of germination rate until twelfth days except SC (M), 20\% were extinct at ninth day,

Table 1 Analysis of variance for germination rate (\%) of different maize inbred hybrids and their parental lines

\begin{tabular}{llrlll}
\hline $\begin{array}{l}\text { Source of vari- } \\
\text { ation }\end{array}$ & Sum of square & $d f$ & Mean square & $F$ & Sig. \\
\hline Between groups & 0.286 & 6 & 0.48 & 1.759 & 0.112 \\
Within groups & 3.600 & 133 & 0.27 & & \\
Total & 3.886 & 139 & & & \\
\hline
\end{tabular}

$d f$ degree of freedom, Sig. significance, Significance level $=p<0.05$ 
Fig. 1 Germination rate (\%) at day 5, 7.9 and 12 of inbred hybrids and their parental lines

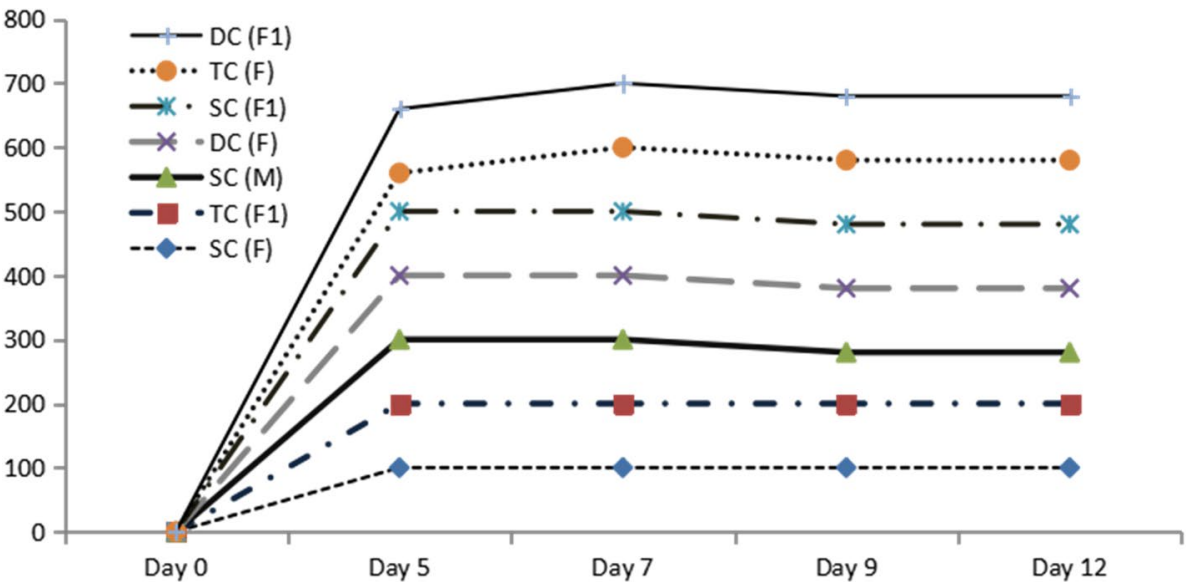

Table 2 Analysis of variance for shoot length of different maize inbred hybrids and their parental lines

\begin{tabular}{lrrrrr}
\hline $\begin{array}{l}\text { Source of vari- } \\
\text { ation }\end{array}$ & Sum of square & $d f$ & Mean square & $F$ & Sig. \\
\hline Between groups & 102.779 & 6 & 17.130 & 2.216 & 0.045 \\
Within groups & 1027.887 & 133 & 7.728 & & \\
Total & 1130.666 & 139 & & & \\
\hline
\end{tabular}

$d f$ degree of freedom, Sig. significance, Significance level $=p<0.05$

and TC $(\mathrm{F})$ was the latest variety to complete germination at seventh day (Fig. 1).

The result also indicates all $\mathrm{F}_{1}$ hybrid seeds, viz. TC $\left(\mathrm{F}_{1}\right)$, SC $\left(\mathrm{F}_{1}\right)$, DC $\left(\mathrm{F}_{1}\right)$ together with parents $\mathrm{SC}(\mathrm{F})$ and DC (F) showed a better performance in terms of mean germination percentage where it reached $100 \%$ germination on the fifth day compared to parents of SC (M) and TC (F) at seventh day.

Fig. 2 Shoot length $(\mathrm{cm})$ at day $5,7,9$ and 12 of inbred hybrids and their parental lines

\section{Shoot length}

The ANOVA table (Table 2) showed that the significance level is $0.045(p=0.045)$, which is below 0.05 . There were statistically significant differences in the mean shoot length between groups of maize varieties. The result (Fig. 2) showed the hybrid $\mathrm{SC}\left(\mathrm{F}_{1}\right)$ produced the highest shoot length $(7.9 \mathrm{~cm})$, followed by DC $\left(\mathrm{F}_{1}\right)$ with $7.6 \mathrm{~cm}$ and $\mathrm{TC}$ (F) $7.4 \mathrm{~cm}$. The SC (F) recorded the lowest shoot length with $4.4 \mathrm{~cm}$ (12 days after sowing).

The table (Table 3) revealed that there was a significant difference between the shoot length of the selected maize varieties in $\mathrm{SC}(\mathrm{F})$ and $\mathrm{SC}\left(\mathrm{F}_{1}\right) p=0.023, \mathrm{SC}(\mathrm{F})$ and $\mathrm{DC}$ $\left(\mathrm{F}_{1}\right) p=0.032, \mathrm{SC}\left(\mathrm{F}_{1}\right)$ and $\mathrm{TC}(\mathrm{F}) p=0.006, \mathrm{TC}(\mathrm{F})$ and $\mathrm{DC}\left(\mathrm{F}_{1}\right) p=0.008$. Moreover, there were no significant differences for the rest of the varieties.

\section{Root length}

The ANOVA table (Table 4) shows that the highly statistically significant difference occurs $0.001(p=0.001)$ in the

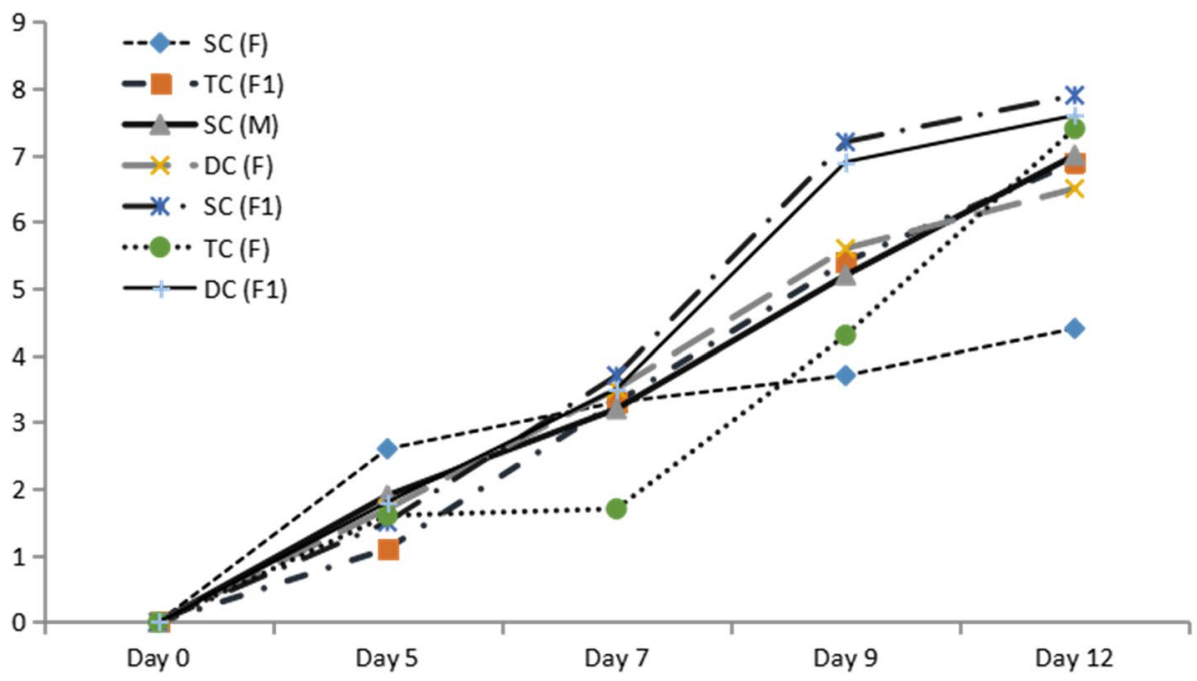


Table 3 Difference in shoot length of inbred hybrids and their parental lines-post hoc test, LSD

\begin{tabular}{|c|c|c|c|c|c|c|}
\hline \multicolumn{3}{|l|}{ Variable } & \multirow{2}{*}{$\begin{array}{l}\text { Mean difference } \\
-1.13500\end{array}$} & \multirow{2}{*}{$\frac{\text { Std. Error }}{0.87912}$} & \multirow{2}{*}{$\begin{array}{l}\text { Sig. } \\
0.199\end{array}$} & \multirow{2}{*}{$\begin{array}{l}\text { Inference } \\
\text { Not significan }\end{array}$} \\
\hline Shoot length & $\mathrm{SC}(\mathrm{F})$ & $\mathrm{TC}(\mathrm{F} 1)$ & & & & \\
\hline & & $\mathrm{SC}(\mathrm{M})$ & -0.66000 & 0.87912 & 0.454 & Not significant \\
\hline & & $\mathrm{DC}(\mathrm{F})$ & -1.26000 & 0.87912 & 0.154 & Not significant \\
\hline & & $\mathrm{SC}(\mathrm{F} 1)$ & $-2.01500^{*}$ & 0.87912 & 0.023 & Significant \\
\hline & & $\mathrm{TC}(\mathrm{F})$ & 0.46000 & 0.87912 & 0.602 & Not significant \\
\hline & & $\mathrm{DC}(\mathrm{F} 1)$ & $-1.90000^{*}$ & 0.87912 & 0.032 & Significant \\
\hline & $\mathrm{TC}\left(\mathrm{F}_{1}\right)$ & $\mathrm{SC}(\mathrm{F})$ & 1.13500 & 0.87912 & 0.199 & Not significant \\
\hline & & $\mathrm{SC}(\mathrm{M})$ & 0.47500 & 0.87912 & 0.590 & Not significant \\
\hline & & $\mathrm{DC}(\mathrm{F})$ & -0.12500 & 0.87912 & 0.887 & Not significant \\
\hline & & $\mathrm{SC}(\mathrm{F} 1)$ & -0.88000 & 0.87912 & 0.319 & Not significant \\
\hline & & $\mathrm{TC}(\mathrm{F})$ & 1.59500 & 0.87912 & 0.072 & Not significant \\
\hline & & $\mathrm{DC}(\mathrm{F} 1)$ & -0.76500 & 0.87912 & 0.386 & Not significant \\
\hline & $\mathrm{SC}(\mathrm{M})$ & $\mathrm{SC}(\mathrm{F})$ & 0.66000 & 0.87912 & 0.454 & Not significant \\
\hline & & TC (F1) & -0.47500 & 0.87912 & 0.590 & Not significant \\
\hline & & $\mathrm{DC}(\mathrm{F})$ & -0.60000 & 0.87912 & 0.496 & Not significant \\
\hline & & $\mathrm{SC}(\mathrm{F} 1)$ & -1.35500 & 0.87912 & 0.126 & Not significant \\
\hline & & $\mathrm{TC}(\mathrm{F})$ & 1.12000 & 0.87912 & 0.205 & Not significant \\
\hline & & $\mathrm{DC}(\mathrm{F} 1)$ & -1.24000 & 0.87912 & 0.161 & Not significant \\
\hline & $\mathrm{DC}(\mathrm{F})$ & $\mathrm{SC}(\mathrm{F})$ & 1.26000 & 0.87912 & 0.154 & Not significant \\
\hline & & $\mathrm{TC}(\mathrm{F} 1)$ & 0.12500 & 0.87912 & 0.887 & Not significant \\
\hline & & $\mathrm{SC}(\mathrm{M})$ & 0.60000 & 0.87912 & 0.496 & Not significant \\
\hline & & $\mathrm{SC}(\mathrm{F} 1)$ & -0.75500 & 0.87912 & 0.392 & Not significant \\
\hline & & $\mathrm{TC}(\mathrm{F})$ & 1.72000 & 0.87912 & 0.053 & Not significant \\
\hline & & $\mathrm{DC}(\mathrm{F} 1)$ & -0.64000 & 0.87912 & 0.468 & Not significant \\
\hline & $\mathrm{SC}\left(\mathrm{F}_{1}\right)$ & $\mathrm{SC}(\mathrm{F})$ & $2.01500 *$ & 0.87912 & 0.023 & Significant \\
\hline & & $\mathrm{TC}(\mathrm{F} 1)$ & 0.88000 & 0.87912 & 0.319 & Not significant \\
\hline & & $\mathrm{SC}(\mathrm{M})$ & 1.35500 & 0.87912 & 0.126 & Not significant \\
\hline & & $\mathrm{DC}(\mathrm{F})$ & 0.75500 & 0.87912 & 0.392 & Not significant \\
\hline & & $\mathrm{TC}(\mathrm{F})$ & $2.47500^{*}$ & 0.87912 & 0.006 & Significant \\
\hline & & $\mathrm{DC}(\mathrm{F} 1)$ & 0.11500 & 0.87912 & 0.896 & Not significant \\
\hline & $\mathrm{TC}(\mathrm{F})$ & $\mathrm{SC}(\mathrm{F})$ & -0.46000 & 0.87912 & 0.602 & Not significant \\
\hline & & TC (F1) & -1.59500 & 0.87912 & 0.072 & Not significant \\
\hline & & $\mathrm{SC}(\mathrm{M})$ & -1.12000 & 0.87912 & 0.205 & Not significant \\
\hline & & $\mathrm{DC}(\mathrm{F})$ & -1.72000 & 0.87912 & 0.053 & Not significant \\
\hline & & $\mathrm{SC}(\mathrm{F} 1)$ & $-2.47500^{*}$ & 0.87912 & 0.006 & Significant \\
\hline & & $\mathrm{DC}(\mathrm{F} 1)$ & $-2.36000 *$ & 0.87912 & 0.008 & Significant \\
\hline & $\mathrm{DC}\left(\mathrm{F}_{1}\right)$ & $\mathrm{SC}(\mathrm{F})$ & $1.90000 *$ & 0.87912 & 0.032 & Significant \\
\hline & & $\mathrm{TC}(\mathrm{F} 1)$ & 0.76500 & 0.87912 & 0.386 & Not significant \\
\hline & & $\mathrm{SC}(\mathrm{M})$ & 1.24000 & 0.87912 & 0.161 & Not significant \\
\hline & & $\mathrm{DC}(\mathrm{F})$ & 0.64000 & 0.87912 & 0.468 & Not significant \\
\hline & & $\mathrm{SC}(\mathrm{F} 1)$ & -0.11500 & 0.87912 & 0.896 & Not significant \\
\hline & & $\mathrm{TC}(\mathrm{F})$ & $2.36000^{*}$ & 0.87912 & 0.008 & Significant \\
\hline
\end{tabular}

$L S D$ least significant difference

*The mean difference is significant at the $p<0.05$ level mean of root length between groups of maize varieties. From the result (Fig. 3) shows, variety $\mathrm{TC}\left(\mathrm{F}_{1}\right)$ produce the highest root length $(14.9 \mathrm{~cm})$, followed by $\mathrm{DC}\left(\mathrm{F}_{1}\right)$ with $13.9 \mathrm{~cm}$ and $\mathrm{SC}\left(\mathrm{F}_{1}\right) 12.9 \mathrm{~cm}$, and the lowest value was obtained at $\mathrm{SC}(\mathrm{M})$ with $7.3 \mathrm{~cm}$ of root length (12 days after sowing).
The LSD post hoc test (Table 5) revealed that most of the varieties showed highly significant differences for root length; between variety $\mathrm{SC}(\mathrm{F})$ and $\mathrm{TC}\left(\mathrm{F}_{1}\right) p=0.02, \mathrm{SC}(\mathrm{F})$ and $\mathrm{DC}(\mathrm{F}) p=0.022, \mathrm{SC}(\mathrm{F})$ and $\mathrm{SC}\left(\mathrm{F}_{1}\right) p=0.042, \mathrm{SC}(\mathrm{F})$ and $\mathrm{DC}\left(\mathrm{F}_{1}\right) p=0.009, \mathrm{TC}\left(\mathrm{F}_{1}\right)$ and $\mathrm{SC}(\mathrm{M}) p=0.002, \mathrm{TC}$ 
Table 4 Analysis of variance for root length of different maize inbred hybrids and their parental lines

\begin{tabular}{lrrrrr}
\hline $\begin{array}{l}\text { Source of vari- } \\
\text { ation }\end{array}$ & Sum of square & $d f$ & Mean square & $F$ & Sig. \\
\hline Between groups & 604.599 & 6 & 100.766 & 4.184 & 0.001 \\
Within groups & 3203.506 & 133 & 24.087 & & \\
Total & 3808.104 & 139 & & & \\
\hline
\end{tabular}

$d f$ degree of freedom, Sig. significance; Significance level $=p<0.05$

$\left(\mathrm{F}_{1}\right)$ and TC $(\mathrm{F}) p=0.018, \mathrm{SC}(\mathrm{M})$ and $\mathrm{DC}(\mathrm{F}) p=0.002, \mathrm{SC}$ $(\mathrm{M})$ and $\mathrm{SC}\left(\mathrm{F}_{1}\right) p=0.005, \mathrm{SC}(\mathrm{M})$ and $\mathrm{DC}\left(\mathrm{F}_{1}\right) p=0.001$, $\mathrm{DC}(\mathrm{F})$ and TC $(\mathrm{F}) p=0.020, \mathrm{SC}\left(\mathrm{F}_{1}\right)$ and TC $(\mathrm{F}) p=0.038$, $\mathrm{TC}(\mathrm{F})$ and $\mathrm{DC}\left(\mathrm{F}_{1}\right) p=0.008$. However, there were no significant differences for the rest of the varieties (Fig. 4).

\section{Discussion}

The present investigation was carried out to determine the differences in performance of some hybridization pathways on seed germination characteristics. Our findings discovered the germination test and seedling evaluation which normally done between the fourth and seventh day after sowing by Brasil (2009). They suggest that this is the best recommended time to get optimal evaluation results as each hybrid has a different growth performance. The fact that we found that the germination of maize seeds started after the third day and completely germinated on the seventh day after sowing, and all $\mathrm{F}_{1}$ hybrid seeds performed better and reached $100 \%$ germination on the fifth day.

The results of seed germination indicated that $F_{1}$ hybrid seeds germinate faster than the parental lines. This is because in maize, $\mathrm{F}_{1}$ hybrid seeds have a superior germination capacity as compared to their parental inbred lines, where hybrid seedlings elongate faster, both roots and shoots (Sarkissian et al. 1964). According to Meena et al. (2018), mature seeds of the male and female parents of the $F_{1}$ hybrid exhibited significantly higher seed weight but showed slower seed germination rates. This result indicates that the heterosis was manifested in the early seed germinating stage in the $F_{1}$ hybrid used. Guo et al. (2013) reported that hybrid seeds were fully germinated within $48 \mathrm{~h}$ and showed early onset of heterosis in radicle emergence. Romagnoli et al. (1990) noted that maize $F_{1}$ hybrid seeds have a superior germination capacity compared to the parental lines, while the molecular basis for heterosis for the emergence of radicals is still unknown.

However, because the percentage of germination rate is dependent on other factors, determining the factors that influence germination test becomes more challenging. At low temperatures, delayed germination occurs due to the difficulties in reorganized cell membranes (Carvalho et al. 2009), and it is also influenced by the physiological quality and the plant genotype (Grzybowski et al. 2015). Meanwhile, according to Bewley and Black (1982), seed germination, emergence and vigour are also controlled by genetic factors, and it has been demonstrated on a genotypic variation on seedling growth.

The results obtained showed a higher speed and more uniformly of the shoot elongation for hybrid seeds as compared to their parents. These findings suggest that hybrids seeds have better shoot elongation ability than the parent and it was due to the heterotic effect of the combination of two parental genes. As expected, three-way cross hybrids $\left(\mathrm{TC}\left(\mathrm{F}_{1}\right)\right)$ were most uniform shoot elongation followed by double-crossing hybrids $\left(\mathrm{DC}\left(\mathrm{F}_{1}\right)\right)$, and the highest was revealed in single cross hybrids $\left(\mathrm{SC}\left(\mathrm{F}_{1}\right)\right)$. However, the findings revealed contrasting in rooting performances, which the highest root elongation was from the three-way cross $\left(\mathrm{TC}\left(\mathrm{F}_{1}\right)\right.$ followed by double-crossing
Fig. 3 Root length $(\mathrm{cm})$ at day 5, 7, 9 and 12 of inbred hybrids and their parental lines

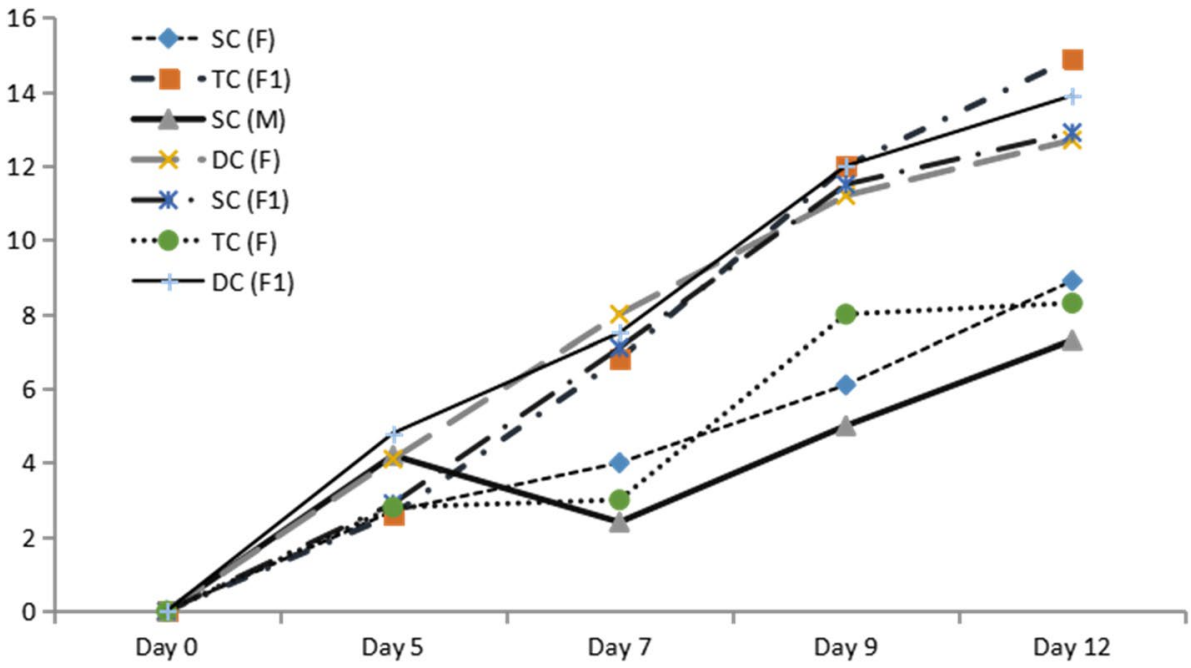


Table 5 Difference in root length of inbred hybrids and their parental lines-post hoc test, LSD

\begin{tabular}{|c|c|c|c|c|c|c|}
\hline \multicolumn{3}{|l|}{ Variable } & \multirow{2}{*}{$\frac{\text { Mean difference }}{-3.64000^{*}}$} & \multirow{2}{*}{$\begin{array}{l}\text { Std. Error } \\
1.55198\end{array}$} & \multirow{2}{*}{$\begin{array}{l}\text { Sig. } \\
0.020\end{array}$} & \multirow{2}{*}{$\begin{array}{l}\text { Inference } \\
\text { Significant }\end{array}$} \\
\hline Root length & $\mathrm{SC}(\mathrm{F})$ & $\mathrm{TC}(\mathrm{F} 1)$ & & & & \\
\hline & & $\mathrm{SC}(\mathrm{M})$ & 1.30500 & 1.55198 & 0.402 & Not significant \\
\hline & & $\mathrm{DC}(\mathrm{F})$ & $-3.59000 *$ & 1.55198 & 0.022 & Significant \\
\hline & & $\mathrm{SC}(\mathrm{F} 1)$ & $-3.18000^{*}$ & 1.55198 & 0.042 & Significant \\
\hline & & $\mathrm{TC}(\mathrm{F})$ & 0.07500 & 1.55198 & 0.962 & Not significant \\
\hline & & $\mathrm{DC}(\mathrm{F} 1)$ & $-4.12000 *$ & 1.55198 & 0.009 & Significant \\
\hline & $\mathrm{TC}\left(\mathrm{F}_{1}\right)$ & $\mathrm{SC}(\mathrm{F})$ & $3.64000^{*}$ & 1.55198 & 0.020 & Significant \\
\hline & & $\mathrm{SC}(\mathrm{M})$ & $4.94500^{*}$ & 1.55198 & 0.002 & Significant \\
\hline & & $\mathrm{DC}(\mathrm{F})$ & 0.05000 & 1.55198 & 0.974 & Not significant \\
\hline & & $\mathrm{SC}(\mathrm{F} 1)$ & 0.46000 & 1.55198 & 0.767 & Not significant \\
\hline & & $\mathrm{TC}(\mathrm{F})$ & $3.71500 *$ & 1.55198 & 0.018 & Significant \\
\hline & & $\mathrm{DC}(\mathrm{F} 1)$ & -0.48000 & 1.55198 & 0.758 & Not significant \\
\hline & $\mathrm{SC}(\mathrm{M})$ & $\mathrm{SC}(\mathrm{F})$ & -1.30500 & 1.55198 & 0.402 & Not significant \\
\hline & & $\mathrm{TC}(\mathrm{F} 1)$ & $-4.94500 *$ & 1.55198 & 0.002 & Significant \\
\hline & & $\mathrm{DC}(\mathrm{F})$ & $-4.89500 *$ & 1.55198 & 0.002 & Significant \\
\hline & & $\mathrm{SC}(\mathrm{F} 1)$ & $-4.48500 *$ & 1.55198 & 0.005 & Significant \\
\hline & & $\mathrm{TC}(\mathrm{F})$ & -1.23000 & 1.55198 & 0.429 & Not significant \\
\hline & & $\mathrm{DC}(\mathrm{F} 1)$ & $-5.42500 *$ & 1.55198 & 0.001 & Significant \\
\hline & $\mathrm{DC}(\mathrm{F})$ & $\mathrm{SC}(\mathrm{F})$ & $3.59000 *$ & 1.55198 & 0.022 & Significant \\
\hline & & $\mathrm{TC}(\mathrm{F} 1)$ & -0.05000 & 1.55198 & 0.974 & Not significant \\
\hline & & $\mathrm{SC}(\mathrm{M})$ & $4.89500^{*}$ & 1.55198 & 0.002 & Significant \\
\hline & & $\mathrm{SC}(\mathrm{F} 1)$ & 0.41000 & 1.55198 & 0.792 & Not significant \\
\hline & & $\mathrm{TC}(\mathrm{F})$ & $3.66500^{*}$ & 1.55198 & 0.020 & Significant \\
\hline & & $\mathrm{DC}(\mathrm{F} 1)$ & -0.53000 & 1.55198 & 0.733 & Not significant \\
\hline & $\mathrm{SC}\left(\mathrm{F}_{1}\right)$ & $\mathrm{SC}(\mathrm{F})$ & $3.18000 *$ & 1.55198 & 0.042 & Significant \\
\hline & & $\mathrm{TC}(\mathrm{F} 1)$ & -0.46000 & 1.55198 & 0.767 & Not significant \\
\hline & & $\mathrm{SC}(\mathrm{M})$ & $4.48500 *$ & 1.55198 & 0.005 & Significant \\
\hline & & $\mathrm{DC}(\mathrm{F})$ & -0.41000 & 1.55198 & 0.792 & Not significant \\
\hline & & $\mathrm{TC}(\mathrm{F})$ & $3.25500 *$ & 1.55198 & 0.038 & Significant \\
\hline & & $\mathrm{DC}(\mathrm{F} 1)$ & -0.94000 & 1.55198 & 0.546 & Not significant \\
\hline & $\mathrm{TC}(\mathrm{F})$ & $\mathrm{SC}(\mathrm{F})$ & -0.07500 & 1.55198 & 0.962 & Not significant \\
\hline & & $\mathrm{TC}(\mathrm{F} 1)$ & $-3.71500 *$ & 1.55198 & 0.018 & Significant \\
\hline & & $\mathrm{SC}(\mathrm{M})$ & 1.23000 & 1.55198 & 0.429 & Not significant \\
\hline & & $\mathrm{DC}(\mathrm{F})$ & $-3.66500 *$ & 1.55198 & 0.020 & Significant \\
\hline & & $\mathrm{SC}(\mathrm{F} 1)$ & $-3.25500 *$ & 1.55198 & 0.038 & Significant \\
\hline & & $\mathrm{DC}(\mathrm{F} 1)$ & $-4.19500 *$ & 1.55198 & 0.008 & Significant \\
\hline & $\mathrm{DC}\left(\mathrm{F}_{1}\right)$ & $\mathrm{SC}(\mathrm{F})$ & $4.12000^{*}$ & 1.55198 & 0.009 & Significant \\
\hline & & $\mathrm{TC}(\mathrm{F} 1)$ & 0.48000 & 1.55198 & 0.758 & Not significant \\
\hline & & $\mathrm{SC}(\mathrm{M})$ & $5.42500^{*}$ & 1.55198 & 0.001 & Significant \\
\hline & & $\mathrm{DC}(\mathrm{F})$ & 0.53000 & 1.55198 & 0.733 & Not significant \\
\hline & & $\mathrm{SC}(\mathrm{F} 1)$ & 0.94000 & 1.55198 & 0.546 & Not significant \\
\hline & & $\mathrm{TC}(\mathrm{F})$ & $4.19500 *$ & 1.55198 & 0.008 & Significant \\
\hline
\end{tabular}

$L S D$ least significant difference

*The mean difference is significant at the $p<0.05$ level hybrids $\left(\mathrm{DC}\left(\mathrm{F}_{1}\right)\right)$ and single cross hybrids $\left(\mathrm{SC}\left(\mathrm{F}_{1}\right)\right)$. According to Ashakina et al. (2016), the findings from three separate studies show that a subset of double cross hybrid lines exhibit extreme rooting behaviours than parental genotypes in tomatoes. Yıldırım and Cakmak
(2018) explained that the three-way cross performed better than the other hybrids and parents because the ratio of chromosomal structures will increase with the number of parents involved in the crossing procedures. Thus, detailed genetics studies are required to explain this occurrence. 
Fig. 4 Different maize varieties seeds at 5, 7, 9, and 12 day of incubation time

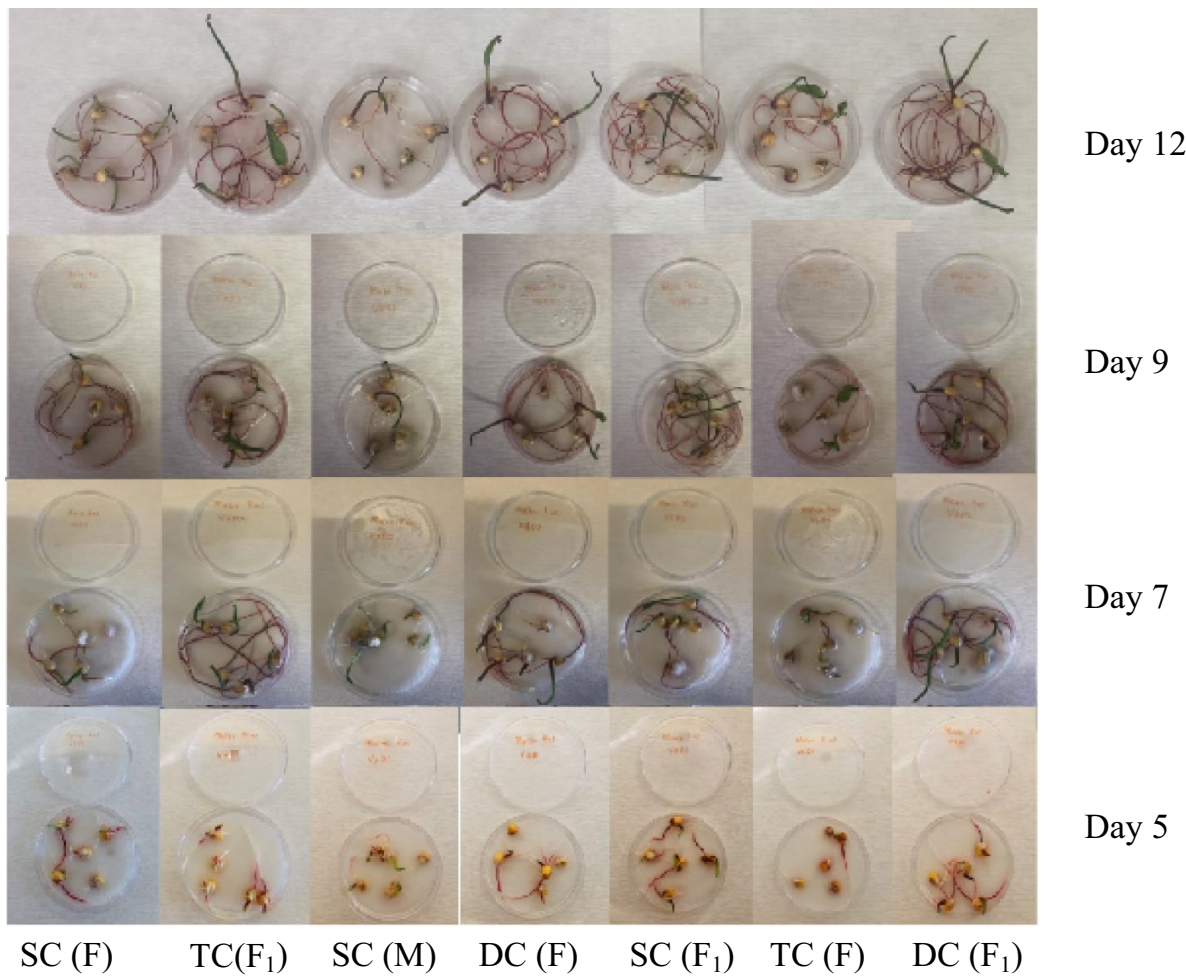

In addition, according to Hochholdinger et al. (2018), the superior root strength of a hybrid seed compared to its parent lineage is studied at the proteome level, and this finding provides new insights on complex proteomic interactions of complex maize root systems during development.

In summary, the findings revealed that maize seeds germinated after the third day and fully germinated on the seventh day after sowing. Varieties SC (F1), DC (F1), and TC (F1) showed excellent germination performance with a $100 \%$ germination rate on the fifth day and produced the highest shoot and root lengths with $7.9 \mathrm{~cm}, 7.6 \mathrm{~cm}$, and $6.9 \mathrm{~cm}$ (shoot length) and $12.9 \mathrm{~cm}, 13.9 \mathrm{~cm}$ and $14.9 \mathrm{~cm}$ (root length), respectively. Thus, the results obtained reveal that the hybrid seeds have a higher germination rate (100\%), and the seedlings were more vigorous than the parents.

Acknowledgments This work was carried out within the framework of the Thematic Program of Excellence with support of the project TKP2020-NKA-24 entitled "Protein Feed Program for the Qualitative and Quantitative Development of Hungarian Agriculture and the Strengthening of the Welfare of Society". We would like to thank the financial support of Researchers Recruitment Programme of National Agricultural Research and Innovation Centre (Gödöllő, Hungary).

Funding Open access funding provided by Hungarian University of Agriculture and Life Sciences.

Open Access This article is licensed under a Creative Commons Attribution 4.0 International License, which permits use, sharing, adaptation, distribution and reproduction in any medium or format, as long as you give appropriate credit to the original author(s) and the source, provide a link to the Creative Commons licence, and indicate if changes were made. The images or other third party material in this article are included in the article's Creative Commons licence, unless indicated otherwise in a credit line to the material. If material is not included in the article's Creative Commons licence and your intended use is not permitted by statutory regulation or exceeds the permitted use, you will need to obtain permission directly from the copyright holder. To view a copy of this licence, visit http://creativecommons.org/licenses/by/4.0/.

\section{References}

Abbasian A, Moemeni J, Rahmani M, Oskoii B, Hamidi A, Sedghi M (2013) Comparison of different hybrid maize seed size with smaller under sieve size in standard germination, cold, accelerated ageing and electrical conductivity tests. Tech J Eng Appl Sci 3:385-393

Ashakina A, Hasanuzzaman Md, Arifuzzaman Md, Rahman Md, Kabir Md (2016) Performance of single, double and three-way cross hybrids in tomato (Lycopersicon esculentum Mill.). J Food Agric Environ 1414:71-77

Association of Official Seed Analysis (AOSA) (1992) Rules for testing seeds. J Seed Technol 6:1-125

Baldwin IT, Halitschke R, Paschold A, Von Dahl CC, Preston CA (2006) Volatile signaling in plant-plant interactions: "talking trees" in the genomics era. Science 311:812-815

Berzy T, Záborszky S, Marton LC, Spitkó T, Pintér J, Tóthné Zsubori Z, Szőke C (2020) Effect of seed deterioration, seed dressing agents and seed vigours parameters in maize (Zea mays $\mathrm{L}$ ) hybrids. Int J Agric Environ Bioresearch 5(2):72-81

Bewley JD, Black M (1982) Physiology and biochemistry of seeds in relation to germination. Springer, New York 
Brasil (2009) Regras para análise de sementes (RAS). In: Brasil. Regras análise de sementes (RAS). https://www.gov.br/agricultura/pt-br/ assuntoa/insumos-agropecuarios/arquivos-publicacoes-insumos/ 2946_regras_analise_sementes.pdf

Britannica (1998) The editors of encyclopaedia. "Heterosis". Encyclopedia Britannica, 20 Jul. 1998. https://www.britannica.com/scien ce/heterosis. Accessed 10 July 2021

Byrum JR, Copeland LO (1995) Variability in vigour testing of maize (Zea mays L.) seed. Seed Science and Technology (Switzerland)

Carvalho LF, Sediyama CS, Reis MS, Dias DCFS, Moreira MA (2009) Influência da temperatura de embebição da semente de soja no teste de condutividade elétrica para avaliação da qualidade fisiológica. Revista Brasileira De Sementes 31(1):9-17. https://doi. org/10.1590/S0101-3122200900

Copeland LO, McDonald MB (1999) Seed vigor and vigor tests. In: Principles of seed science and technology, chapter (7), pp 153180. https://doi.org/10.1007/978-1-4615-1783-2

Fortuna A, Oreamuno MAA, Maria G, Lucarelli L, Marocco E, Milo M (2020) Food outlook-Biannual report on global food markets. In Food outlook-Biannual report on global food markets (Issue June). https://doi.org/10.4060/ca9509en

Franck WJ (1950) Introductory remarks concerning a modified working of the international rules for seed testing on the basis of experience gained after the World War. Proc Int Seed Test Assoc 16:405-430

Goggi AS, Caragea P, Pollak L, McAndrews G, DeVries M, Montgomery $K$ (2008) Seed quality assurance in maize breeding programs: tests to explain variations in maize inbreds and populations. Agron J 100(2):337-343. https://doi.org/10.2134/agronj2007.0151

Grzybowski CRS, Vieira RD, Panobianco M (2015) Teste de estresse na avaliação do vigor de sementes de milho. Revista Ciência Agronômica 46(3):590-596. https://doi.org/10.5935/1806-6690. 201500

Guo B, Chen Y, Zhang G, Xing J, Hu Z et al (2013) Comparative proteomic analysis of embryos between a maize hybrid and its parental lines during early stages of seed germination. PLoS ONE 8(6):e65867. https://doi.org/10.1371/journal.pone.0065867

Hochholdinger F, Marcon C, Baldauf JA, Yu P, Frey FP (2018) Proteomics of MAIZE ROOT DEVELOPMEnt. Front Plant Sci 9:143. https://doi.org/10.3389/fpls.2018.00143

Marcos FJ (2015) Seed vigor testing: an overview of the past, present and future perspective. Scientia Agricola 72(4):363-374. https:// doi.org/10.1590/0103-9016-2015-0007

Marton LC (2013) Hybrid maize in Hungary is 60 years old. In: 60 Years of Hungarian hybrid maize. Pannonian Plant Biotechnology Association, pp 10-16

Meena RK, Pullaiahgari D, Gudipalli P (2018) Proteomic analysis of heterotic seed germination in maize using $F_{1}$ hybrid DHM 117 and its parental inbreds. Turkish J Biol 42(4):345-363. https:// doi.org/10.3906/biy-1803-13

Nagy J (2008) Maize production: food, energy biomass. Akadémiai Kiadó, Budapest. ISBN: 9789630586368

Romagnoli S, Maddaloni M, Livini C, Motto M (1990) Relationship between gene expression and hybrid vigor in primary root tips of young maize. Theor Appl Genet 80:769-775

Rouf Shah T, Prasad K, Kumar P (2016) Maize - a potential source of human nutrition and health: a review. Cogent Food Agric. https:// doi.org/10.1080/23311932.2016.1166995

Sarkissian IV, Kessinger MA, Harris W (1964) Differential rates of development of heterotic and nonheterotic young maize seedlings, I. Correlation of differential morphological development with physiological differences in germinating seeds. Proc Natl Acad Sci 51:212-218

Shirin M, Enayatgholizadeh MR, Siadat E, Fathi G (2008) Comparison of suitable seed vigour of hybrid Zea mays (CV. SC.704) in the field condition of Ahvaz. In: Proceeding of the 10th congeres of agronomy plant breeding, vol 330

Yildirım M, Cakmak M (2018) Evaluation of hybrid seeds of three-way and single cross for grain number and weight in bread and durum wheat. Turkish J Agric Food Sci Technol 6(1):22-27 